\title{
GDPR és a köznevelési intézmények - a GDPR bevezetésének 13+1 lépése a köznevelési intézményekben
}

\author{
Albert Ágota \\ adatvédelmi tisztviselö \\ dralbertagota @gdprszakszeruen.hu
}

\section{GDPR in the institutions of public education}

The topic of this presentation is the steps of the formation of an adequate data protection of the GDPR instructions in the institutions of public education and the discussion of the most important problems, which are particularly related to these institutions: how can we start becoming GDPR-compatible? What are the greatest obstacles (besides the issue of how to take pictures) and "how we can put out the fire"? How does an institution of public education differ from a "simple" member of any market?

Since the 25th of May, 2018, these institutions - independent from their maintainer - are being regulated by the GDPR, which means a great challange to them. Apart from the vast amount of data that has to be processed daily, they face situations like

- the processing of data is regulated by a number of sector laws (law on educational register, law on public education, Public Servants' Act, Labour Code, law on taxes, etc.)

- the special composition of the data subjects (children, parents, employees, other data subjects)

- as data controllers they have complex social network (maintainer, local authority, community of parents, student organizations, churches, supervising organs, different authorities, business partners, foreign partner intitutions etc.), through which significant transfers of personal data happen

- they can process data not only as data controllers but also as data processors, (e.g.: secondary school entrance exams, organizing high level "érettségi" etc.) and

- the supervision of employees and students requires a different approach from schools than from a traditional member of the market (using the followings (e.g.): register of working hours, video monitoring system, smart devices and internet in the possession of institutions).

Keywords: GDPR, public education, data protection

Hogyan válhat egy intézmény GDPR-kompatibilissé?

\section{1. lépés}

Tudatositsuk, a GDPR igen is vonatkozik az intézményünkre. Ha homokba dugjuk a fejünket és azt mondjuk hogy nem, attól még igen. Söt, mindenért az adatkezelö, azaz az intézményvezető a felelős egyszemélyben. Azonban nem elég, ha csak az igazgató érzi úgy, a nyakába szakadt még egy teljesítendő feladat, hanem az 
iskola minden alkalmazottjának tudnia kell, ha adatot kezel, azt a GDPR elöírásainak megfelelően kell tennie. Vonatkozik ez az osztályfőnökökre, a rendszergazdára, az iskolapszichológusra és a portásra is, mindenkire, aki valamilyen módon személyes adattal kapcsolatba kerül. Természetesen más adatokhoz fér hozzá egy gazdaságis és másokhoz a könyvtáros, éppen ezért fontos, hogy mindenki tisztában legyen a jogosultságával és felelősségi körével.

\section{2. lépés}

Vegyünk igénybe szakembert. A rendelet alkotói úgy gondolták, az iskolák mint közérdek alapján közfeladatot végrehajtó intézmények az adatvédelem szempontjából „veszélyes üzemek”, ezért kötelező adatvédelmi tisztviselőt (a szakzsargonban DPO-t) kinevezniük. Ez a fenntartó kötelessége, a kinevezés elmaradása GDPR-ellenes. Az adatvédelem speciális ismereteket követel, amelyek nem lesznek meg attól, hogy például egy pedagógusra rátestáljuk ezt a feladatot. Söt, előtanulmányok nélkül egy-két napos intenziv GDPR kurzus is maximum annyira elég, hogy az áldozatban tudatosuljon, mennyi mindent nem tud. Olyan személy sem lehet DPO, aki munkaköréből adódóan felelős az adatvédelmi szabályozás betartásáért (pl. az intézmény vezetője).

Az adatvédelmi tisztviselő csak tanácsokat adhat, a döntés az adatkezelőé, ahogy a felelösség is.

\section{3. lépés}

Térképezzük fel, milyen személyes adatokat kezel az iskolánk. Ahogy az egészségügy, úgy a köznevelés is elképzelhetetlen adathegyek nélkül.

Az adatok feltérképezéséhez elkerülhetetlen az olyan alapfogalmak megismerése, pl. mi a személyes adat és mit jelentenek a személyes adat különleges kategóriái, hiszen ezek pontos behatárolása nélkül elsikkadhatnak igen fontos adatkezelések. Személyes adat egy osztályzat? Igen. És különleges személyes adat az, hogy Bence vagy Hanna mogyoróallergiás? Igen. És az személyes adat, hogy az ötödikesek közül a magas vörös kölyök intöt kapott? Igen, amennyiben az ötödikesek között annyi magas vörös kölyök van, hogy már ennyi információval is beazonositható az adott diák.

Aharmadik lépés tehát fellelniaz intézménybenaszemélyes adatokat, beazonositani az adatkezeléseket és olyan adattérképeket gyártani, amelyek alapján tisztázható egy-egy adat életútja, azaz

- melyik adat honnan és hogyan érkezett be (szülötöl, tanulótól, fenntartótól stb.),

- ki kezeli azt házon belül (titkárság, osztályfönök, gazdaságis kolléga stb.),

- hol és hogyan tároljuk (papiron, elektronikusan vagy mindkettőn),

- hogyan, hova és mi alapján továbbitjuk (lásd a köznevelési törvény felsorolását) és

- mikor kell leselejtezni (megsemmisiteni) azt. 


\section{4. lépés}

Tisztítsuk meg az adatvagyont. A felesleges munka elkerülése érdekében el kell döntenünk, hogy mely adatot kezelhetjük tovább és melyet nem. Föbb szempontok:

- azadott adat kezelése megfelelazalapelveknek? Jogszerüen, tisztességesen és átláthatóan kezeljük?

- van jogalapunk az adott személyes adat kezelésére? Ha nincs, akkor vagy teljesiteni kell a hivatkozott jogalaphoz szükséges feltételt (pl. be kell szerezni a hozzájárulást), vagy kiméletlenül ki kell selejtezni (meg kell semmisiteni) azt. A "mindig így szoktuk” jogalapot a GDPR nem ismeri, a hozzájárulás pedig - a közhiedelemmelellentétben - nem univerzálisan használhatójogalap, mivelaz bármikor visszavonható, illetve egyes helyzetekben (pl. alá- és fölérendeltségi viszonyban, megkérdőjelezhetö önkéntesség esetén) nem alkalmazható.

- idöben szavatos még az adott adat? A vonatkozó jogszabályok (pl. 20/2012. (VIII. 31.) EMMI rendelet 1. sz. melléklete), illetve az intézményünk irattári terve tájékoztatást nyújt, hogy melyik adat meddig örizhetö. Ha lejárt a megörzési idö, a kezelés nem jogszerü.

- szükség van az adott adatkezelésre? Van konkrét cél vagy csak raktározzuk az adatot, majd csak jó lesz valamire? Ha nincs cél, az adat kezelése nem jogszerü.

- az adatkezelés céljának eléréséhez feltétlen szükség van az adott adatra? A GDPR elkötelezett hive az adattakarékosságnak, azaz nem támogatja olyan adat kezelését, amely nem szükséges az adott cél eléréséhez. A felesleges adatoktól szintén meg kell szabadulnunk.

- helyes, pontos az adat? Ha nem az, akkor kijavítható, helyesbíthetö? Ha nem, döntenünk kell a sorsáról. A pontatlan, hibás személyes adat is személyes adat.

- megfelelő biztonságot biztosítunk az adatnak?

Minél nagyobb és minél régebbi az intézményünk, annál nagyobb a feltérképezés és kiválogatás munkaigénye, ráadásul nem ez az a feladat, amit gyakornokokra felelösen rá lehetne bízni.

Ha lekarcsúsitottuk az adatvagyonunkat, jöhet az adattérképek újrarajzolása. Ezek már alkalmas kiinduló pontjai az iskola adatkezelési nyilvántartásának, amely a GDPR alapján kötelező, és amelyet egy adatvédelmi hatósági ellenőrzés során az elszámoltathatóság elvének megfelelően - be kell tudni mutatnunk. Ahogy az iskola leltározza a számítógépeit, labdáit meg csontvázait, úgy az adatkezeléseit is leltároznia kell.

\section{5. lépés}

Határozzuk meg az egyes adatkezelések követelményeit. Az adatkezelések döntő többségében jogszabályok határozzák meg, hogy milyen adatot kezelhet, hova továbbithat az iskola. Az iskolák közérdekü feladataik végrehajtásához szükséges adatkezeléseknél a jogalap a GDPR 6. cikk (1) bekezdés e) pontjában meghatározott közérdek lesz és ez a jogalap - a felügyeleti hatóság álláspontja szerint - elnyeli a 
további adatkezelési jogalapokat, valamint be kell tartani a GDPR alapelveit is.

Vannak olyan adatkezelések, amelyek bonyolultabbak, mint egy átlag munkáltató adatkezelései. Egy iskolában pl. sokkal nehezebb a munkahelyi és magánhasználatot elkülöníteni - decemberben a pedagógus használatában lévő számítógépröl keresettbeiglireceptakarácsonyivacsorához kellvagyahagyományokkalfoglalkozó osztályfönöki órára? A cicalány007@ e-mail cím a titkos barátnő címe vagy egy diák anyukájáé, netalán magáé a diáké? Talán nincs még egy olyan munkáltató, ahol a magánszférát olyan nehéz elválasztani a munkahelyi kötelezettségek teljesítésétől, mint egy átlagos iskola.

Lehet még „problémás” adatkezeléseket sorolni, pl. a "normál” körülmények között általában jogos érdekre hivatkozó adatkezelésekhez milyen jogalap használható az iskolákban? Például:

- az intézményben felszerelt kamerák felvételeivel,

- a diákok internethasználatának ellenörzésével,

- az iskolai rendezvényen készült tömegfelvételekkel kapcsolatos adatkezelés, amelyeken nemcsak a ballagó diák van, hanem közeli és távoli rokonsága nullától száz éves korig, és amely képek a modern technikának köszönhetően bármikor portréfotó minőségre nagyithatók.

Az adattovábbitások vizsgálata is szükséges, hiszen az iskola nemcsak jogszabály alapján továbbit adatokat harmadik személyeknek, hanem pl. testvériskolai kapcsolattartás vagy versenyekre jelentkezés keretében is. Söt, iskolai kórustalálkozót szervezhetnek pl. Kínában, amely harmadik országnak számít, szállást pedig oda is foglalni kell sok-sok személyes adat megadásával. Ráadásul az adattovábbítást nyilván kell tartanunk, különben hogyan fogjuk tudni megmondani az érintettnek, hogy mikor, hova, kinek, mi alapján és milyen garanciákkal továbbitottuk a személyes adatait?

Kétségeink eldöntésében segitséget nyújthatnak a NAlH anyagai. ${ }^{1}$

\section{6. lépés}

Igazítsuk a belső szabályzatainkat és utasításainkat a GDPR elöírásaihoz. Az iskoláknak kötelező adatvédelmi szabályzatot késziteniük, a GDPR azonban a konkrét tartalmat az adatkezelöre bízza.

Mi legyen benne? Amit fontosnak tartunk, pl::

- adatkezelések részletes leírása, különösen a speciális eseteké (pl. tanulmányi és tantestületi kirándulással, iskolaújsággal, intézményi honlappal kapcsolatos adatkezelések, dokumentum másolatok kezelése stb.)

- adatfeldolgozókkal kapcsolatos rendelkezések, illetve az olyan adatkezelések leírása, amelyek esetében az iskolánk adatfeldolgozó (pl. központi felmérések, tanulmányi versenyek stb.) 
- érintetti jogok leirása és a jogok érvényesitésének módja (az érintetti tájékoztatás formái és kötelező tartalma, érintetti kérelmekre válaszadásnak, a hozzájárulás visszavonásának, az adatkezelés ellen tiltakozásnak, törlési kérelemnek adminisztrációja stb.)

- kötelező, illetve elszámoltathatósági szempontból fontos nyilvántartások tartalma (pl. az adatkezelések, adattovábbitások és adatvédelmi incidensek nyilvántartása stb.)

- adatvédelmi incidens esetén követendő protokoll elöre elkészített nyomtatványokkal, nehogy a nagy kapkodásban kimaradjon valami,

- olyan speciális adatkezelések, mint osztálycsoport létrehozása közösségi oldalon, oktatással kapcsolatos appok használata (pl. Kahoot!), tanárok-diákok saját loT-eszközeinek használata stb.

- beépitett adatvédelem érvényesitéséhez szükséges eljárások (pl. adatok biztonságos tárolásának, továbbitásának módja, jogosultságok kiosztásának elvei stb.)

- az adatvédelmi tisztviselö feladatai és hatásköre.

- Az adatvédelmi és adatbiztonsági szabályzaton kivül szükségünk van még egyéb dokumentumokra is, $\mathrm{pl}$.

- speciális szabályzatok megalkotása (kameramüködtetési, beléptetési, informatikai, információ biztonsági, image policy stb.)

- érdekmérlegelési tesztek végzésének eljárásrendje, kockázatfelmérés és kezelés módszerei stb.

\section{7. lépés}

Készitsük el az adatkezelési tájékoztatókat. A GDPR sarkalatos pontja az érintettek tájékoztatása, ennek elmaradása komoly szankciókat vonhat maga után annyi kedvezménnyel, hogy költségvetési intézmény esetén a maximális közigazgatási bírság 20 millió forint.

Milyen tájékoztatókra van szükség? Célszerü minimum három adatkezelési tájékoztatót késziteni, egyet a diákoknak, egyet a szülöknek, egyet pedig az alkalmazottaknak. A fenntartónak gondolnia kell még olyan egyéb érintettekre is, mint pl. a szerződéses partnerek, nekik is kell késziteni tájékoztatót.

Az általános adatkezelési tájékoztató általában az iskola honlapján kap helyet, de mindenképpen kell nyomtatott verzió is, amely az intézmény titkárságán bármikor elérhető. A speciális, egy-egy adatkezelésre vonatkozó tájékoztatók helyet kaphatnak pl. a beiratkozási és hozzájárulást kérő nyomtatványokon is, így késöbb nincs vita a tekintetben, hogy megtörtént-e az érintettek szükséges tájékoztatása.

\section{8. lépés}

Ültessük át a gyakorlatba a gyerekekkel kapcsolatos eltéréseket. Pl. mi legyen a 14-18 év közötti gyerekkel illetve akkor, ha nagykorú lesz a diák? Ki férhet hozzá a tanuló adataihoz, ki gyakorolja a szülöi felügyeleti jogot? A szülőnek mindenröl joga van tudni, vagy adott esetben a szülövel szemben is védeni kell a gyermek jogait? Elmondhatja-e az iskola, hogy informatika órán milyen témákra keresett 
rá a tinédzser a neten, vagy jobb ezekröl hallgatni? Milyen plusz garanciákat kell beépíteni az adatkezelésekbe akkor, ha az érintett 18 éven aluli?

A GDPR alapján a diákoknak szóló adatkezelési tájékoztatót úgy kell megfogalmazni, hogy korosztályuknak megfelelö mértékben ők is megérthessék az abban foglaltakat és legyenek tisztában pl. azzal, hogy nem kell nekik olyan fotót eltürniük az iskola honlapján, amelyen nagyon nem tetszenek maguknak. A tájékoztató készülhet sok oldalas írásos verzióban, de érdemes megfontolni a videofilm vagy képregény formátumot is.

\section{9. lépés}

Tegyünk azért, hogy az érintettek gyakorolhassák jogaikat, betartva a jogszabályban foglalt határidőt. Nem szabad elfelejtenünk, hogy a szülök speciális érintettek egyrészt saját jogon, másrészt gyermekeik miatt, frusztrációjuk pedig az egeket verheti pl. azért, mert a fiuk vagy lányuk egyfolytában a fülüket rágja, milyen elönytelen kép van róluk az iskola honlapján és legyenek szivesek, intézkedjenek a kép eltávolíttatása érdekében. Éppen ezért célszerü az érintetti kérelmek megfelelő rendezése érdekében a belsö adatkezelési szabályzatban részletesen rögzíteni az eljárásrendet és minden esetben bevonni az adatvédelmi tisztviselőt is.

\section{0. lépés}

Alakítsuk ki az adatvédelmi incidens protokollunkat - és nemcsak a leírása fontos, hanem a begyakorlása is, akár próbaincidens keretében. A 72 órás hatósági bejelentési határidő nagyon rövid és minden egyes bejelentés egyben önfeljelentés is, amely vizsgálatot von maga után. Az incidenskezelés pedig nem annyi, hogy széttárjuk a kezünket, ez most igy sikerült, máskor majd biztos gondosabbak leszünk és kicsit nehezebben lopják majd el a tanáriból a nyitott ablakon keresztül azt a laptopot, amely titkositás nélkül tartalmazott adatot több száz gyerekröl és szüleikröl.

\section{1. lépés}

$\mathrm{Ne}$ felejtkezzünk el a beépített adatvédelemröl. A GDPR összetolja az adatkezelést és az adatvédelmet, az adatkezelőnek pedig mindent meg kell tennie annak érdekében, hogy az érintettek a lehető legnagyobb biztonságban tudják a személyes adataikat. Az adatbiztonság fontos része pl. a számítógépes rendszer védelme, de ide tartoznak olyan triviális dolgok is, mint a jogosultságok kiosztása, a jelszavakkal kapcsolatos elöírások betartatása, a rendszeres biztonsági mentés, a tiszta asztal politika, a szekrények és fiókok zárása, a leselejtezett papírok megsemmisitése stb. Ajánlatos megismerkednünk olyan technikákkal is, mint az álnevesités, az anonimizálás és a titkositás és figyelembe kell venni mindezeket már az adatkezelések megtervezése folyamán is.

\section{2. lépés}

Oktatás és bevezetés. A polcra feltett 500 oldalnyi szabályzat még nem jelenti azt, hogy az iskolánk megfelel a GDPR követelményeinek. Az adatvédelmi kultúrának be kell épülnie a mindennapokba, és nemcsak beépülnie kell, hanem bizonyítanunk 
is tudni kell, hogy a rendeletnek megfelelöen jártunk el. Ehhez szükséges az alkalmazottak képzése, hiszen nem egy személyben az igazgató kezeli az adatokat, hanem minden egyes tanár, pedagógiai asszisztens és még a portás is. Ez nem azt jelenti, hogy mindenkinek tudnia kell mindent, hanem azt, hogy a saját területén mindenki sajátitsa el a szükséges ismereteket, és ne csak bemagolja, hanem alkalmazza is az elöirásokat. Az elvileg és általában képzéseknek semmi értelme, csakis annak, ha az alkalmazottak munkaköri szintjükhöz kapcsolódva szereznek értelmezhető tudást.

\section{3. lépés}

Nemzetközi kapcsolatok. Az iskoláknak szerteágazó nemzetközi kapcsolatai lehetnek, és nemcsak a nemzetiségi iskoláknak, hanem a két tanitási nyelvüeknek, nyelvtagozatosoknak és a "sima” intézményeknek is. A nemzetközi kapcsolatok elengedhetetlen része az adattovábbitás külföldi illetőségü adatkezelő vagy nemzetközi szervezet számára, akár személyes adatok, akár különleges adatok formájában. A GDPR alapján az Európai Gazdasági Térség országai belföldnek számitanak és vannak olyan országok is, amelyek a Bizottság véleménye szerint garantálják az uniós védelemnek megfelelö védelmi szintet, ilyen pl. Svájc, Japán és Uruguay, míg olyan országok, mint az Egyesült Államok, Ukrajna vagy Szerbia harmadik országnak számítanak. Ezekbe az országokba irányuló adattovábbítás esetén speciális feltételeknek kell teljesülnie, amelyek fennállását az iskolának kell bizonyitania akkor is, ha csak Kárpátaljára ruccan ki egy pár napra a 10/a. osztály.

\section{3 + 1. lépés}

Kövessünk nyomon az eseményeket és reagáljunk, ha szükséges. Kétszer ugyanabba a folyóba nem lehet belelépni és ez igaz az adatvédelemre is. Még ha az uniós rendelet maga nem is változik gyakran, a hazai ágazati jogszabályok bármikor módosulhatnak, ahogy várhatóan a jogértelmezés is idővel egyre kifinomultabb lesz. Nemcsak arra van szükség, hogy az iskola ellenörizze a saját adatvédelmi gyakorlatát és folyamatosan az újabb és újabb igényekhez igazitsa azt, hanem arra is, hogy a jogértelmezésnek megfelelő irányvonalat kövesse. Ez az a terület, ahol szintén elengedhetetlenül szükséges az adatvédelmi tisztviselö közremüködése. 